\section{Grundig bagklogskab}

Henrik Preben Perregaard, Økonomisk teorihistorie - $i$ et humanistisk perspektiv, Systime, Århus 2001, 424 sider, 375 kr.

En diger sag på ikke mindre end 400 særdeles tætskrevne sider udgør det første forsøg på dansk på at gennemspille den økonomiske teorihistorie. Og så er opgaven med at anmelde værket endog endnu mere tyngende, end antallet af ord og ligninger indikerer. Det er nemlig ikke bare en bog, men nok så meget et liv, der står til bedømmelse. Bogen er blevet til gennem årtier hen over alvorlig psykisk sygdom, fyring fra Økonomisk Institut, faglig marginalisering, ja snart sagt al anden modgang end skilsmisse, og værket samler en stor del af Perregaards samlede forskningsindsats. Alt dette lægger forfatteren ikke skjul på, idet han nu lægger sit livsværk frem og nervøst overlader det til andre at vurdere, 'om barnet er velskabt'. Som med så meget andet afhænger dommen givetvis af øjnene, der ser.

De fleste fagøkonomer vil - at dømme efter den udprægede mangel på interesse for fagets videnskabsfilosofiske og historiske dimensioner - se en ligegyldig og uanvendelig skabning, men de vil dog nikke anerkendende ved tanken om den enorme grundighed i skabelsesakten, der har afstedkommet babyen. Forfatteren selv vil efter alt at dømme se en lille oprører, der skriger på J. M. Keynes og sandt menneskelige økonomer i en generelt kold og overmatematiseret forskerver- den. Og idéhistorikeren vil mærke et stik i hjertet, når hun kigger ned $\mathrm{i}$ vuggen og ser en enøjet økonom, der ofte stirrer stift frem for sig, i stedet for en lille idéhistoriker med et øje på hver finger, der kigger dybt forundret på menneskets forvirrende aktiviteter. En nærmere undersøgelse vil dog vise, at barnet kigger på verden fra en lidt skæv vinkel med sit ene øje sammenlignet med den neoklassiske normalbaby, der dominerer økonomiens fødeklinikker. Men meget anderledes er barnets perspektiv ikke set med idéhistorikerens øjne, selvom det har fået stemplet ordene 'nyt og forfriskende anderledes syn' på ryggen.

$\mathrm{Nu}$ er vi jo som idéhistorikere traditioneltyderst tilbageholdende med at definere vores eget fagområde og videnskabelighed, dvs. vores egne ønskebørn. Præsenteret for så blændende skarpt et bagklogskabens lys, som nogle af fortidens tænkere bades i i Perregaards bog, fremstår nogle træk i den ideelle idébistoriske undersøgelse og fremstilling imidlertid pludselig soleklare for ens indre blik. Fx at det må gælde om at nå til en vurdering eller opløsning af selvindlysende sandheder og fordomme (jævnfør Kristensen og Schmidt: Lys luft og renlighed, s. 7 - en af meget få positive bestemmelser af idéhistorisk faglighed). Og om at idéhistorikeren evigt bestræber sig på at løse den umulige opgave at rekonstruere fortidige tænkeres forståelseshorisont.

Der er tilløb til den slags bestræbelser i Perregaards bog, fx i den efterhånden obligatoriske inddragelse af Adam Smiths moralfilosofi 
som perspektiv på økonomiteorien. Men generelt gælder det, at den kronologiske gennemgang af tænkere bare bliver bedre og bedre, efterhånden som Perregaards mestendels nutidige økonomiske perspektiv får større og større overensstemmelse med de præsenterede teoretikeres egen tilgang. I kombination med Perregaards dybe interesse for Marx betyder det, at fremstillingen fra Marx til Keynes, hvor Perregaards projekt desværre stopper, er både særdeles kvalificeret og interessant.

Det stive blik falder mest én for brystet i bogens begyndelse, hvor formaliserede økonomiske selvfølgeligheder i stedet for at blive problematiseret gennem studiet af fortiden ofte ophæves til fuldgyldigt perspektiv på den. Perregaard lægger således ud med at konstatere, at Hesiod for 2800 år siden var den første til at fastslå, 'hvori det økonomiske problem i det hele taget består', idet Hesiod introducerer 'det moderne knaphedsbegreb'. Det må siges at være forud for sin tid! 'Knaphedsproblemet' i økonomiens specifikke form (fordelingen af knappe ressourcer blandt konkurrerende mål) bygger jo på et moderne generaliseret behovsbegreb, som HansJørgen Schanz i Trak af behovsproblematikkens idébistorie på eksemplarisk idéhistorisk vis demonstrerer som historisk frembragt for få århundreder siden.

Tilsvarende oplever man i Økonomisk teoribistorie Aristoteles' overvejelser helt ukritisk blive sat på moderne formel - helt bogstaveligt - og sågar analyseret ud fra en noget komplice- ret 'Edgeworth-Box'. Det har i øvrigt det lidt groteske resultat, at man skal have et vist kendskab til moderne økonomisk formalisering for overhovedet at forstå gennemgangen af de gamle grækere og Bibelen.

Nu er det jo ikke direkte fejlagtigt, at Aristoteles i sine samfundsovervejelser rejser et spørgsmål, der kan identificeres som en eftersøgning af 'betingelserne for det neoklassiske Pareto-optimum, som kontraktkurven i Edgeworth-Box-diagrammet jo udtrykker'. Men det er svært at se, at det (eller en vurdering af Aristoteles' teknisk-formalistiske formåen) kan være interessant for ret mange, lige som det næppe var et vigtigt anliggende for Aristoteles selv. Højst kan det bekræfte os, nærmere bestemt økonomerne, i, at vi er meget klogere i dag. Til gengæld burde det ikke være uinteressant for nogen, hvordan problemfelter, som vi i dag vil identificere som 'økonomiske', tematiseres helt anderledes hos Platon og Aristoteles, idet de er spundet ind $\mathrm{i}$ en altomfattende helhed af politik, etik osv., der kuliminerer i en kosmologi. Det burde mane til eftertanke helt ind $i$ de mest ensidigt tænkende økonomiske neoklassikeres rækker. En sådan helt anderledes verdensforståelse $\mathrm{i}$ antikken kunne $\mathrm{fx}$ anskueliggøres gennem en analyse af arbejdsdelingen i Platons Staten, der umiddelbart ligner den produktivitetsfremmende ditto hos Smith og frem, men i realiteten har en helt anden begrundelse. Den illustrative mulighed forpasser Perregaard mindst halvt.

Med Perregaards efterrationaliserende analyse kan det lade sig 
gøre, at merkantilister beskæftiger sig med 'malthusiansk befolkningsteori', før Malthus overhovedet blev født, og John Stuart Mill kan være 'den eneste af de klassiske økonomer, der klart skelner mellem Walras' lov, Say's ligning og Say's identitet' - et halvt århundrede før, Walras publicerede noget som helst. Og merkantilisternes rente- og skatte-overvejelser kommer til at markere et højdepunkt inden for den økonomiske tænkning (der først overgås med Keynes i 1930'erne) på et tidspunkt, hvor den økonomiske videnskab fra et traditionelt idéhistorisk synspunkt slet ikke eksisterede, bl.a. fordi den slet ikke havde etableret et genstandsområde.

Perregaard kan ellers sin Thomas S. Kuhn, sine paradigmer og videnskabsteorien i det hele taget. Hans Videnskabsteori for okonomer - en introduktion fra 1992 er faktisk ikke ueffen - og da slet ikke i forhold til det almindelige niveau af selvrefleksion på økonomiinstitutterne. Faktisk er bogen fortsat enestående i Danmark. Derfor er det overraskende, at en Karl Popper-agtig indfaldsvinkel til økonomiteoriens udvikling og en rent kumulativ videnslogik er så stærkt dominerende.

Som en lidt bagklog gennemgang af den teknisk-formalistiske udvikling inden for den økonomiske videnskab, før den eksisterede, og en grundig indføring i udviklingen efter dens opståen i 17-1800-tallet, er bogen faktisk en storslået bedrift. Bogen er desuden garneret med en vis mængde oplivende materialhistorie og biografisk stof, og det er vel primært deri, det 'humanistiske perspektiv', der er bogens undertitel, består. I begyndelsen og slutningen af bogen er indføjet nogle resultater af en undersøgelse af miljø og holdninger blandt forskerøkonomer på danske læreanstalter i firserne. De virker lidt påklistrede. Blev de klippet fra, og blev bogen opdateret med udviklingstræk efter Keynes, har den seriøsiteten og substansen til at gøre sig i selskab med tilsvarende (bagkloge) angelsaksiske værker.

\section{Carsten Fenger-Gron}

\section{Den evige fred}

Rebecka Lettevall, En europeisk kosmopolit. En idéhistorisk studie av Immanuel Kants $\mathrm{Om}$ den eviga freden och dess verkningshistoria (Doktorafhandling ved Humanistiska fakulteten, Lunds Universitet; forsvaret d. 23.5.2001.), Brutus Östlings Bokförlag, Symposion, Stockholm/Stehag 2001, 288 sider.

Da Kant døde i 1804, fandtes der allerede 2800 værker omhandlende hans filosofi, og man kan roligt regne med, at dette antal er vokset til et uoverskueligt antal i de efterfølgende næsten to hundrede universitetsekspansive år. Aspirerende Kant-forskere behøver dog ikke nødvendigvis at fortvivle over, hvordan deres eget bidrag skal kunne klare sig i dette hav af kommentarlitteratur - dels er store dele af det forudgående af meget varierende 